Петрук В. А. [1; ORCID ID: 0000-0001-8840-0575] к.Т.Н., доцент,

Петрук I. P. [1; ORCID ID: 0000-0002-4800-1374] к.е.н., доцент

${ }^{1}$ Національний університет водного господарства та природокористування, м. Рівне

\title{
СТАТИСТИЧНИЙ АНАЛІЗ СТАНУ, ЕФЕКТИВНОСТІ ТА ПОТЕНЦІАЛУ ТУРИЗМУ В РІВНЕНСЬКІЙ ОБЛАСТІ
}

У статті виділено природні та історико-культурні рекреаційні, туристичні об'єкти Рівненської області. Розкрито новітні підходи до визначення ефективності внеску туристичних підприємств у розбудову економіки від їх функціонування. Системно проаналізовано стан і динаміку їх використання, ефективність, проблеми та потенціал розвитку. Встановлено критично низький рівень їх освоєння, експлуатації та віддачі на сучасному етапі. Описано вплив нестабільної політичної, складної економічної та соціально-культурної ситуації в країні, пандемії коронавірусу та введення карантину на зменшення кількості туристів. Виявлено основні проблеми розвитку туристичної індустрії, які потребують невідкладної державної підтримки та регулювання.

Ключові слова: рекреаційні ресурси; туристичні продукти; економічний ефект; соціальний ефект; туристичний потенціал; стратегія розвитку туризму.

Постановка проблеми. Світовий досвід вказує, що туристична діяльність $€$ високорентабельною і динамічно розвинутою сферою господарювання. У сучасному світі туризм належить до найпотужніших i найдинамічніших галузей економіки та регіонального розвитку. За даними Всесвітньої туристичної організації частка туризму в світовому ВВП становить близько 9\% і близько 30\% у світовому експорті послуг та 6\% від обсягів світової торгівлі. За даними Всесвітньої туристичної організації, щорічно подорожує більше 800 млн чоловік. Більш ніж в 40 країнах світу туризм є основним джерелом надходжень національного бюджету. Однією з головних ознак світового туризму на сучасному етапі $€$ його сталий розвиток, концепція якого успішно реалізується у багатьох країнах світу. Щодо України, то за умов наявності унікальних природно-рекреаційних ресурсів, історико-культурних пам'яток, багатої флори та фауни, різноманітних зон відпочинку, які виступають одним із чинників сталого розвитку туризму, 
спостерігається критично низький рівень освоєння, експлуатації та віддачі рекреаційно-туристичного потенціалу. Не $є$ виключенням і Рівненська область.

Аналіз останніх досліджень і публікацій дозволив з'ясувати, що вже все частіше і частіше приділяється увага проблемам становлення та розвитку туристичної сфери як самостійної галузі господарського комплексу як Рівненської області так і інших регіонів та країни в цілому. Вивченню вказаних питань присвятили свої праці ряд вітчизняних і зарубіжних учених. Серед них Л. О. Василькевич,
Н. І. Коніщева,
Н. О. Кушірович,
С. І. Коротун,
В. Д. Олійник

Л. В. Павленко,

Г. А. Папирян,

В. Ю. Стельмах,

Т. І. Ткаченко,

А. М. Хахлюк, П. Самуэльсон, В.Нордхаус та інші. В працях цих науковців досліджуються різноманітні аспекти становлення та розвитку туризму, однак питання визначення соціально-економічної ефективності туристичної сфери конкретного регіону не знайшли однозначного трактування і залишається дискусійним питанням, на яке немає однозначної відповіді.

Невирішені раніше частини загальної проблеми. Визначення особливостей природних та історико-культурних рекреаційних, туристичних об'єктів у конкретному регіоні, зокрема, в Рівненській області, та їх ефективності, ще $€$ не достатньо висвітленими і потребують подальшого ґрунтовного дослідження.

Постановка завдання. Враховуючи, що кожен регіон, кожна область має свої конкретні особливості, метою статті є виділення природних та історико-культурних рекреаційних, туристичних об'єктів Рівненської області, аналіз стану, динаміки й ефективності їх використання, проблем та потенціалу розвитку з урахуванням особливостей розвитку місцевого ринку.

Основні результати дослідження. Рівненщина була і $\epsilon$ туристичним регіоном. Саме тому туристична галузь у стратегії розвитку Рівненської області до 2027 року є однією з пріоритетних і розрахована на 7 років. Вона включає в себе промоцію регіону через активізацію спортивного, подієвого, історичного та гастрономічного туризму, агротуризму у «зелених садибах», і стилізованих етнопоселень, де можна навчитися давніх ремесел, і веломаршрутів, котрі з кожним роком облагороджують й розбудовують. На часі відкриття нових продуктів та об'єктів для мандрівників. Їх об'єднала «Рівненщина туристична», що стала частиною інфраструктурного хабу, який створюється у регіоні.

Розроблена концепція «Рівненщина туристична», оновлено бренд-бук, сайт RIVNE.TRAVEL, туристичні продукти. У цій концепції 
виділено три основні блоки, які посилюють сильні сторони краю та впливають на розвиток туризму. Це - зміна балансу між виїзним та внутрішнім туризмом, інтерес міжнародних донорів до проєктів туристичного спрямування, зростання попиту на креативний туристичний продукт.

На початку року підписано розпорядження про оголошення 2020-го Роком промоції культурної спадщини Рівненської області. Цей рік знаменний 500-річчям з часу створення Нобельського Євангелія, ювілеями культурних центрів - Дубна та Острога, а також 560-річчям з дня народження Костянтина Острозького.

Відтак, основними цілями визначено розширення асортименту туристичних продуктів, роботу над підвищенням потенціалу надавачів туристичних послуг, промоцію туристичних продуктів. Туристично успішними для розвитку Рівненщини можуть стати проєкти-магніти. Серед них - мультифункціональна арена на вулиці Макарова у Рівному, Міжнародний аеропорт «Рівне», туристичний комплекс «Дубенський замок», Тараканівський форт, науковоінноваційний парк INN CITY на базі Національного університету водного господарства. Вони дадуть змогу розвивати подієвий, історичний та спортивний туризм. А поєднання духовного та фестивального туризму ще більше розкриє потенціал «Рівненщини туристичної».

Адже Рівненщина має доволі значний рекреаційний потенціал різноманітних природних рекреаційних ресурсів (кліматичних, біологічних, гідрологічних, ландшафтних, джерел мінеральних вод, лікувальних грязей тощо), який здатен задовольнити різноманітні потреби як вітчизняних, так й іноземних туристів. Станом на 1 січня 2020 року площа лісів області складає 805,8 тис. гектарів, лісистість - 40,2 відсотка. Природно-заповідний фонд (ПЗФ) нараховує 315 природно-заповідних об'єктів загальною площею 199,5 тис. гектарів, при цьому відсоток заповідності складає 9,95\%. ПЗФ області представляють: Рівненський природний заповідник (площа 47046,8 га); національні природні парки - 2 (площа - 30767,11 га); регіональні ландшафтні парки - 3 (площа - 58708 га); заказники загальнодержавного значення - 13 (площа - 16720 га) та місцевого значення - 113 (площа - 50713 га); пам'ятки природи загальнодержавного значення - 8 (площа - 420,2 га) та місцевого значення - 62 (площа - 394,4234 га); зоологічний парк загальнодержавного значення - 1 (площа - 11,6 га); дендрологічний парк загальнодержавного значення - 1 (площа - 29,5 га); паркипам'ятки садово-паркового мистецтва загальнодержавного 
значення - 2 (площа - 39 га) та місцевого значення - 13 (площа 137,1962 га); заповідні урочища - 96 (площа - 3328,6 га).

На території області протікає 171 річка загальною довжиною 4,5 тис. км, загальна довжина яких складає 4459 км, з них одна велика - Прип'ять, шість середніх (Стир, Іква, Горинь, Случ, Ствига, Льва) та 164 малі річки. На території області протікають 18 річок міжобласного та міждержавного значення, всі річки належать до басейну правої притоки Дніпра - річки Прип'ять. В області нараховується 150 озер, загальна площа яких становить 29,5 кв. км, сумарний об'єм води - майже 93,1 млн куб. метрів. Серед найбільших озер області - Нобель (4,99 кв. км), Біле (4,53 кв. км), Острівське (1,12 кв. км). Розміщено 12 водосховищ, загальною площею 29,3 тис. га, сумарним об'ємом води 46,8 млн куб. метрів. Найбільші водосховища - Хрінницьке (на річці Стир) і Млинівське (на річці Іква). На території області знаходиться 1688 ставків, які займають площу 8,5 тис. га і акумулюють 93,4 млн куб. метрів води. Понад тисячу водойм передано на умовах оренди для рибогосподарських потреб.

Рівненщина подарувала світу Пересопницьке Євангеліє, на якому присягають на вірність українському народові президенти України, першу у східних слов'ян академію в Острозі, Острозьку типографію і перший український «Буквар».

На Рівненщині, між селами Пляшева та Острів знаходиться Національний історико-меморіальний заповідник «Поле Берестецької битви» - основний меморіальний комплекс козацької слави України де в 1651 році відбулася битва між козацькоселянським військом гетьмана Богдана Хмельницького та польською шляхтою. Розпочав свою діяльність у 1967 році як музей-заповідник «Козацькі могили» (філія Рівненського краєзнавчого музею). У 1991 році отримав статус «державного» і перейменований у Державний історико-меморіальний заповідник «Поле Берестецької битви». У 2008 році заповіднику надано статус «національного».

у 2014-2020 роках в області здійснено комплекс заходів 3 розвитку туризму, становлення місцевого туристичного продукту та формування позитивного туристичного іміджу Рівненщини. Це одна 3 перших областей в Україні, яка розпочала впровадження світової практики розвитку Зелених шляхів (Green Ways).

Досягнення Рівненщини - ефективний процес стратегічного планування, який завершився прийняттям єдиної в Україні Стратегії розвитку туризму Зеленого шляху «Медове коло» на 2018 - 2022 роки. Цей документ $\epsilon$ дорожньою картою для Березнівського, 
Гощанського, Костопільського, Корецького та Рівненського районів, який увійде до європейської мережі Зелених шляхів.

Розпочато роботу із розвитку мережі туристичних маршрутів працює експертна комісія з проведення маркування та знакування туристичних маршрутів області, промарковано 5 маршрутів загальною протяжність понад 400 км: «Поліська січ», «Велика пригода у національному природному парку ДерманськоОстрозький», «Валерина стежка», «Горинський берег», «Велопарк «Ремельський».

Започатковано процес впровадження інноваційного досвіду створення туристичних інформаційних офісів. В області працює 6 туристичних інформаційних офісів у містах Рівне, Острог, Сарни, Корець, смт Володимирець та Дубенському районі.

Одним з вагомих досягнень Рівненщини є ї̈ маркетингова кампанія, спрямована на активізацію туристичних потоків територією області. Так, колекційна туристична гра-квест «На власні очі» - найяскравіша в Україні маркетингова кампанія, яка дозволила значно підвищити інтерес до туристичного потенціалу області та активізувати внутрішні подорожі. Загальне інформаційне охоплення гри - більше 8 тис. осіб.

Туристичний потенціал області представлено на 17-ти всеукраїнських та міжнародних виставках. Проведено 8 інфотурів для представників місцевих та всеукраїнських засобів масової інформації, загальний щорічний тираж видань із публікаціями становить 2 млн екземплярів. Відеролик про Рівненщину щороку транслюються на всіх напрямках потягів Інтер Сіті. Середній щорічний трафік пасажирів - 260 тис. осіб. Крім того, у рамках «Програми розвитку туризму в Рівненській області на 20162020 роки» 3 обласного бюджету видано 15 кредитів на суму 577 тис. грн. У 2017 р. за кошти ДФРР реалізовано проект із реконструкції благоустрою місця відпочинку туристів популярного туристичного об'єкта «Тунель Кохання» у смт Клевань Рівненського району.

3 метою підтримання культурної спадщини в області функціонує існує широка інфраструктура культурних закладів, понад 3000 пам'яток історії, культури та архітектури, регіон зберіг автентичну історико-культурну спадщину Полісся і Волині, що дозволяє розвивати рекреаційний, історичний, екологічний та інші види туризму [10].

У м. Рівне діють два театри (музично-драматичний і театр ляльок) та обласна філармонія. В переліку історичних міст країни, затверджених Указом Президента України, вказані 13 міст Рівненщини: міста Рівне, Дубно, Корець, Острог, Дубровиця, 
Радивилів, Березне, селища міського типу, Володимирець, Гоща, Клевань, Мізоч, Млинів, Степань. Рівненська область нараховує 108 туристичних підприємств. Кількість туристів, які відвідали Рівненську область, обслугованих суб'єктами туристичної діяльності за 2014-2019 рр., наведені в таблиці 1 [9].

Таблиця 1

Туристичні потоки Рівненської області

\begin{tabular}{|c|c|c|c|c|}
\hline \multirow[b]{2}{*}{ Роки } & \multirow[b]{2}{*}{$\begin{array}{c}\text { Кількість туристів, } \\
\text { обслугованих } \\
\text { суб'єктами } \\
\text { туристичної } \\
\text { діяльності області - } \\
\text { усього }\end{array}$} & \multicolumn{3}{|c|}{ Із загальної кількості туристів } \\
\hline & & $\begin{array}{c}\text { іноземні } \\
\text { туристи }\end{array}$ & $\begin{array}{c}\text { туристи - } \\
\text { громадяни } \\
\text { України, які } \\
\text { виїжджали за } \\
\text { кордон }\end{array}$ & $\begin{array}{c}\text { внутрішн } \\
\text { туристи }\end{array}$ \\
\hline 2014 & 8936 & - & 7502 & 1434 \\
\hline 2015 & 6640 & 1 & 5403 & 1236 \\
\hline 2016 & 9022 & - & 7572 & 1450 \\
\hline 2017 & 11168 & - & 9833 & 1335 \\
\hline 2018 & 22027 & - & 20347 & 1680 \\
\hline 2019 & 31428 & - & 28737 & 2688 \\
\hline
\end{tabular}

Становлення туристичної галузі на Рівненщині має важливе значення і для соціально-економічного розвитку області. Зокрема, внесок туристичних підприємств у розбудову економіки проявляється у вигляді економічного і соціального ефектів від їх функціонування. Економічний ефект проявляється у величині надходжень до бюджетів обласного та державного значень, обсягах інвестиційних вкладень у розбудову інфраструктури галузі; а соціальний - у покращенні добробуту суспільства (зменшення рівня безробіття, збереження та відновлення природного потенціалу області та історико-культурної спадщини, підвищення життєвого рівня населення тощо).

Становлення і розвиток туризму в регіоні має більший соціальний ефект, ніж будь-який інший вид діяльності, пов'язаний 3 наданням послуг. Туризм спрямований на задоволення таких важливих потреб людини як відпочинок та оздоровлення. Так, споживаючи туристичні послуги, людина покращує насамперед фізичний і психічний стани.

Крім того, у рамках такого загального позитивного ефекту на розвиток суспільства, який створює туристичний продукт, розвиток інфраструктури туризму сприяє зміцненню економіки регіону, держави за рахунок створення нових робочих місць і розвитку супутніх галузей економіки [3]. 
Слід зазначити, що позитивний вплив туристичної діяльності на економіку регіону визначається через наступні види економічних ефектів:

- прямий ефект - прибутки від об'єктів I групи: доходи туристичних агентств, готелів, ресторанів, історико-культурних об'єктів та інших підприємств туристичної індустрії, а також доходи магазинів від покупок, що здійснюються туристами;

- непрямий ефект - прибутки від об'єктів II групи: доходи будівельних організацій, банків, постачальників продуктів харчування, комунальних служб, які отримані ними від реалізації продукції та послуг об'єктам I групи, а також заробітна плата робітників I групи;

- індукований ефект - прибуток від об'єктів III групи: доходи інших місцевих резидентів у вигляді заробітної плати, дивідендів, орендної плати та інших видів платежів, отриманих ними від реалізації продукції та послуг об'єктами II групи [6, С. 165-177].

Таким чином, прямий вплив туристичної сфери на розвиток економіки регіону визначається купівельними спроможностями туристів, тобто обсягом туристичних послуг та продукції, що можуть i були куплені відпочиваючими. У свою чергу туристичні підприємства потребують певних витрат, пов'язаних із придбанням товарів і послуг інших секторів економіки. Економічна активність останніх, що стає наслідком купівельної поведінки туристів, і $€$ проявом непрямої дії туристичних підприємств на розвиток місцевої економіки. Непрямі та похідні витрати формують вторинні витрати туристичної галузі.

Під час прямих витрат туристів і непрямих витрат коштів обслуговуючими підприємствами накопичуються дохідні ресурси у формі заробітної плати, орендної плати тощо. Додатковий дохід місцеві мешканці можуть витрачати на покупку вітчизняних товарів і послуг, створюючи таким чином новий оберт економічної активності в місцевій економіці.

Економічний ефект від розвитку туризму в регіоні проявляється насамперед в якісних параметрах: підвищенні зайнятості населення, а також у стимулюванні розвитку слабких в економічному відношенні регіонів за рахунок підвищення надходжень до державного і місцевих бюджетів, інвестицій тощо [8, С. 53-54].

Як інформує ГУ ДПС, за результатами 2019 року до місцевих бюджетів Рівненської області надійшло 1375 тис. грн туристичного збору. Ця сума збільшилась на 1020 тис. грн порівняно з відповідним періодом 2018 року, що складає 386,6 відсотка. Динаміку сплати туристичних зборів за період 2014-2019 рр. наведено на рисунку. 


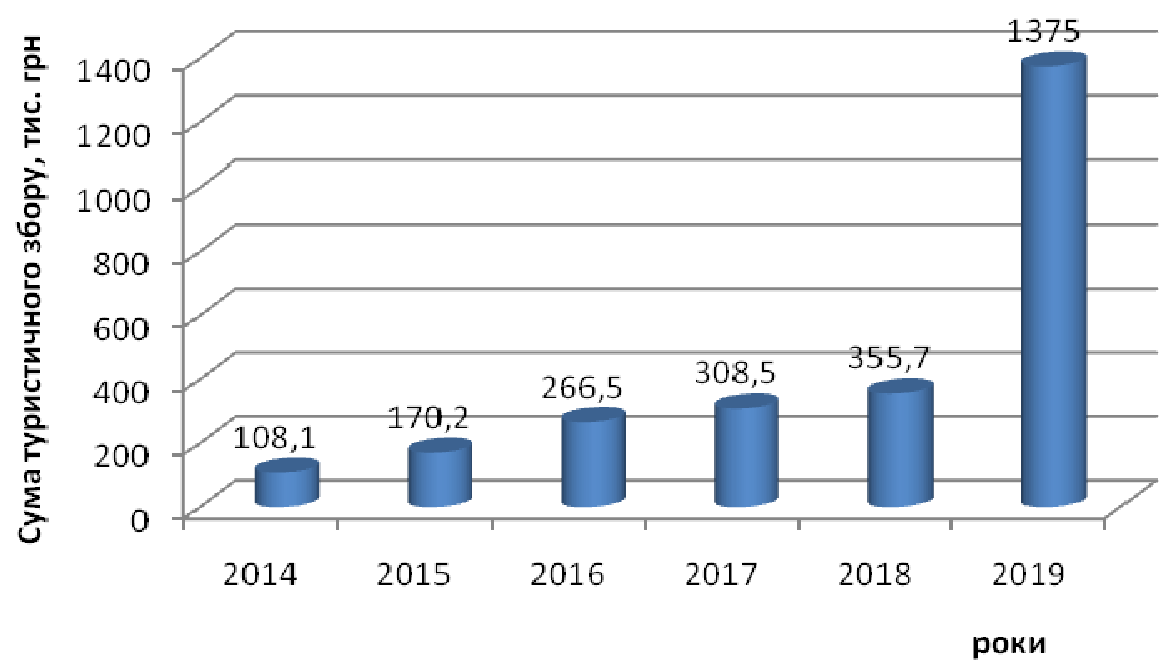

Рисунок. Динаміка сплати туристичного збору за період 2014-2019 років

Найбільші поповнення місцевих скарбниць отримали бюджети міста Рівне - 605,4 тис. грн, Рівненського району - 223,6 тис. грн, Сарненського району - 150,1 тис. грн, Володимирецького району 106,2 тис. грн.

Працівники податкової служби переконані, що збільшення потоку туристів, які відвідують Рівненщину та сплачують туристичний збір, ставку якого встановлюють сільські, селищні та міські ради, сприяє й розвитку бізнесу рівненських суб'єктів господарювання. Адже, оплачуючи різні товари чи послуги, турист робить свою інвестицію у бізнес нашого регіону й наповнення бюджету.

Проте, маючи значні природні ресурси, Рівненська область не використовує їх належним чином для розвитку туристичного сектора економіки. Вважається, що нереалізований туристичний потенціал як Рівненської області так і України в цілому є значно більшим за його реалізовану частину. Результати наукових праць вітчизняних дослідників [2; 4; 5; 7] дозволили виявити основні проблеми розвитку туристичної індустрії, які потребують невідкладної державної підтримки та регулювання, а саме:

- нестабільність політичної ситуації в країні та наявність військового конфлікту на Сході;

- складна економічна, соціально-культурна ситуація в країні;

- недоліки регіонального регулювання галузі туризму;

- недосконале та несприятливе для розвитку туризму нормативно-правове забезпечення; 
- відсутність скоординованої висококваліфікованої системи заходів з просування туристичного продукту на світовий ринок;

- велике податкове навантаження, що $€$ перешкодою для потенційних інвесторів у сферу туризму;

- неврегульований механізм стимулювання розвитку туристичної індустрії на державному рівні;

- недостатній рівень кваліфікації персоналу туристичної сфери;

- низький рівень розвитку туристичної інфраструктури та ії невідповідність світовим стандартам;

- невідповідність вимогам закордонних і вітчизняних туристів транспортної структури тощо.

Для підтримки розвитку туристичної галузі в Україні у 2017 році Кабінетом Міністрів України розроблена і схвалена Стратегія розвитку туризму та курортів на період до 2026 року [1], якою передбачається досягнення показників розвитку туризму, що наведені у таблиці 2.

Таблиця 2

Контрольні показники розвитку сфери туризму та курортів в Україні, передбачені Стратегією розвитку туризму та курортів на період до 2026 року

\begin{tabular}{|c|c|c|c|c|c|}
\hline \multirow{2}{*}{$\begin{array}{l}\text { № } \\
3 / \pi\end{array}$} & \multirow[t]{2}{*}{ Показники } & \multirow[t]{2}{*}{$\begin{array}{l}\text { Один. } \\
\text { вим. }\end{array}$} & \multicolumn{3}{|c|}{$\begin{array}{c}\text { За роками (відносно показників } 2015 \\
\text { року) }\end{array}$} \\
\hline & & & 2019 & 2022 & 2026 \\
\hline 1. & $\begin{array}{l}\text { Кількість іноземних } \\
\text { туристів, які } \\
\text { в"їжджають до } \\
\text { України }\end{array}$ & млн осіб & $\begin{array}{c}\text { збільшення } \\
\text { у } 1,5 \text { рази }\end{array}$ & $\begin{array}{c}\text { збільшення } \\
\text { у } 2 \text { рази }\end{array}$ & $\begin{array}{c}\text { збільшення } \\
\text { у 2,5 рази }\end{array}$ \\
\hline 2. & $\begin{array}{l}\text { Кількість суб'єктів } \\
\text { туристичної } \\
\text { діяльності }\end{array}$ & $\begin{array}{c}\text { тис. } \\
\text { одиниць }\end{array}$ & $\begin{array}{l}\text { збільшення } \\
\text { у } 1,5 \text { рази }\end{array}$ & $\begin{array}{c}\text { збільшення } \\
\text { у } 3 \text { рази }\end{array}$ & $\begin{array}{c}\text { збільшення } \\
\text { у } 5 \text { разів }\end{array}$ \\
\hline 3. & $\begin{array}{l}\text { Обсяг надходжень } \\
\text { до } \\
\text { місцевих бюджетів } \\
\text { від сплати } \\
\text { туристичного збору }\end{array}$ & млн грн & $\begin{array}{c}\text { збільшення } \\
\text { у } 2 \text { рази }\end{array}$ & $\begin{array}{c}\text { збільшення } \\
\text { у } 5 \text { разів }\end{array}$ & $\begin{array}{l}\text { збільшення } \\
\text { у } 10 \text { разів }\end{array}$ \\
\hline 4. & $\begin{array}{l}\text { Обсяг надходжень } \\
\text { до зведеного } \\
\text { бюджету (податки та } \\
\text { збори) від діяльності } \\
\text { суб'єктів туристичної } \\
\text { діяльності }\end{array}$ & $\begin{array}{l}\text { млрд } \\
\text { грн }\end{array}$ & $\begin{array}{c}\text { збільшення } \\
\text { у } 2 \text { рази }\end{array}$ & $\begin{array}{c}\text { збільшення } \\
\text { у } 5 \text { разів }\end{array}$ & $\begin{array}{l}\text { збільшення } \\
\text { у } 10 \text { разів }\end{array}$ \\
\hline
\end{tabular}


продовження табл. 2

\begin{tabular}{|c|l|l|c|c|c|}
\hline 5. & $\begin{array}{l}\text { Кількість робочих } \\
\text { місць у сфері } \\
\text { туризму }\end{array}$ & тис. осіб & $\begin{array}{c}\text { збільшення } \\
\text { у } 1,5 \text { рази }\end{array}$ & $\begin{array}{c}\text { збільшення } \\
\text { у } 3 \text { рази }\end{array}$ & $\begin{array}{c}\text { збільшення } \\
\text { у } 5 \text { разів }\end{array}$ \\
\hline 6. & $\begin{array}{l}\text { Кількість внутрішніх } \\
\text { туристів }\end{array}$ & тис. осіб & $\begin{array}{c}\text { збільшення } \\
\text { у 2 рази }\end{array}$ & $\begin{array}{c}\text { збільшення } \\
\text { у } 3 \text { рази }\end{array}$ & $\begin{array}{c}\text { збільшення } \\
\text { у } 5 \text { разів }\end{array}$ \\
\hline 7. & $\begin{array}{l}\text { Кількість } \\
\text { екскурсантів }\end{array}$ & тис. осіб & $\begin{array}{c}\text { збільшення } \\
\text { у } 1,5 \text { рази }\end{array}$ & $\begin{array}{c}\text { збільшення } \\
\text { у 2 рази }\end{array}$ & $\begin{array}{c}\text { збільшення } \\
\text { у 2,5 рази }\end{array}$ \\
\hline
\end{tabular}

Заплановані результати реалізації Стратегії розвитку туризму та курортів на період до 2026 року є вражаючими. Однак, туризм як багатогалузеве та багатофункціональне явище-феномен характеризується найвищим ступенем еластичності від природних (екологічних), загальноекономічних, соціальних і політичних змін у конкретному регіоні та країні.

Зменшення кількості туристів, які приїжджають в Україну 3 2014 року спричинено останніми подіями, які відбулися в країні, а також тим, що один з найбільших туристичних регіонів нашої країни - півострів Крим - наразі $€$ тимчасово окупованою Російською Федерацією територією. Негативним чинником $є$ також те, що навіть внутрішні туристи можуть надавати перевагу відпочинку за кордоном.

Пандемія коронавірусу та карантин змінили плани багатьох людей. Внаслідок запровадження карантину від березня 2020 року відбулося падіння туристичного потоку на $75 \%$, що спричинило втрату 2\% ВВП країни за рахунок сукупних втрат бізнесу сфери культури, креативних індустрій та туризму, які недоотримали більше 83 млрд грн доходу. Середня завантаженість готелів впала з 50\% до $20 \%$. Середні втрати доходу за 1 вікенд склали - 119,77 млн грн. Крім того, втрати в робочій силі та доходах відкидають галузі туризму, культури і креативних індустрій на рівень 2010 року. Локдаун туризму, культури та креативних індустрій може призвести до втрати близько 10\% ВВП протягом найближчих 5 років.

Однак українці хочуть відпочивати, бачити нові місця. На перший план у такому разі виходить внутрішній туризм i спроможність кожного окремого регіону країни запропонувати вибагливим мандрівникам свої родзинки. Туризм - це математика й аналітика об'єднані з історично-культурною спадщиною і поєднані 3 технічними та матеріальними можливостями. Внутрішній туризм стає основним в умовах послаблення карантину і загострює проблемні моменти цього напрямку. Що стосується Рівненської області то це транспортне сполучення і негативний стан інфраструктури й 
потребує нагального покращення покриття автошляхів, модернізацію аеропорту та автостанцій із наданням різних послуг (мотелі, місця для кемпінгів, заклади харчування тощо).

Якщо згадати історію туризму, можна з впевненістю сказати, що його перші паростки з'явилися ще у Стародавньому світі, адже у далекому VI ст. до н.е. римляни і греки почали здійснювати свої перші подорожі до Єгипту, куди їх приваблювала історія, архітектура і культура цієї дивовижної країни. 3 часом у Стародавньому світі почали масово споруджувати перші заклади розміщення і дороги для мандрівників, з'являється спеціальний транспорт для здійснення далеких подорожей. Все це можна вважати прототипом сучасного туристичного обслуговування, основою формування інфраструктури культурно-пізнавального туризму, який є одним 3 найважливіших чинників формування економіки багатьох країн. Туризм безпосередньо або опосередковано впливає на розвиток близько 50 суміжних галузей, стимулює пожвавлення місцевої економіки та створення додаткових постійних та сезонних робочих місць. Туристське споживання активно підтримує існування та розвиток народних ремесел, національної культурної спадщини. Крім того, туризм - єдина виробнича галузь, що нерозривно пов'язана з людським фактором та спрямована здебільшого на задоволення психофізіологічних потреб людини. Природно людська допитливість, жага знань та нових вражень провокує наповнення ринку туристичних послуг найрізноманітнішими пропозиціями, сприяє проявам здорової конкуренції та ставить перед суб'єктами господарювання нові вимоги. Так, сьогодні, щоб мати шанс на процвітання, рекреаційно-туристична галузь повинна гармонійно поєднувати природно-рекреаційний, культурно-історичний, інфраструктурний потенціал, вдалий менеджмент та оригінальність.

Саме тому, найвідоміші туристичні місця Рівненщини - «Тунель кохання», «Базальтові стовпи», Тараканівський форт і вузькоколійка на Поліссі потроху змінюють свій статус. За останні роки дуже змінилася інфраструктура навколо «Тунелю кохання», активного розвитку набув приватний бізнес 3 готелем і рестораном європейського рівня. Необхідно створити оглядові майданчики і фотозони навколо «Базальтових стовпів». Наразі триває процес зміни власності й передачі від Міноборони Тараканівського Форту. Вузькоколійка знаходиться на балансі Укрзалізниці і графік ії роботи сформований відповідно до потреб місцевого населення, оскільки це важлива транспортна артерія Полісся. Навколо неї інфраструктура нерозвинута, що створює незручності для туристів. Раніше про ці привабливі місця знали лише місцеві жителі, а віднедавна об'єкти 
зацікавили не лише туристів з України, а й з-за кордону. Однак, аби мандрівники хотіли повертатися сюди вдруге, природної краси замало. Необхідно шукати додаткові можливості для цікавого та комфортного перебування гостей.

Впроваджуються комплексні програми розвитку та збереження територій навколо Хрінницького водосховища, озера Білого, вітряних млинів в с. Витків, Красносілля, с. Щекичин Гощанського р-ну, водяного млина в с. Городок Рівненського р-ну, парку та палацусадиби Валевських в Гощі, Юзефінського парку Рокитнівського р-ну. Заслуговують на увагу Надслучанська Швейцарія, джерело Святого Миколая, Музей бурштину, серед експонатів якого - шматки бурштину віком до 40 мільйонів років, знайдені у різний час на території Рівненщини, а також виготовлені з нього ювелірні вироби, Свято-Троїцький Межирецький чоловічий монастир, Березнівський дендрологічний парк, музей Євангелія у с. Пересопниця, Новомалинський замок, 1300-річний дуб-патріарх, що росте в урочищі «Юзефінська дача» Рокитнівського району та інші [11].

Великі надії в області покладаються на екологічний туризм, активний відпочинок у національних парках «Нобельський», «Надслучанський» та «Дермансько-Острозький», проведенні сплавів на байдарках та каное. Частину проєктів заплановано реалізувати разом із сусідньою Волинською областю, зокрема тамтешнім Національним парком «Прип'ять - Стохід».

Екологізація туристичної діяльності, впровадження екологічно безпечних технологій в туризмі сприяють поліпшенню або збереженню природного середовища, що сприяє зростанню туристичної привабливості території. Нині розвитком екотуризму опікуються не лише окремі країни, але й світові організації: Світове товариство охорони природи (IUCV), Всесвітня туристична організація (ВТО), Організація Об'єднаних націй (OOH) тощо. Сучасна світова наука розглядає екологічний туризм як такий, що ґрунтується на активній рекреації у природних ландшафтах і спрямований на збереження екосистем, мінімізацію впливу на природне середовище та збереження інтересів місцевого населення. Тому завдання уряду та туристичних організацій полягає у тому, щоб максимізувати позитивні аспекти впливу туризму на природне середовище та мінімізувати негативні. Сталий розвиток туризму повинен забезпечувати потреби нинішніх туристів без втрат для майбутніх поколінь, і повинен ґрунтуватися на чотирьох основних аспектах: соціальному, природоохоронному, економічному і культурному. 
Важливим критерієм, що впливає на розвиток туризму на місцевому рівні, $€$ ще культура гостинності. В основу розробки i створення моделей ефективних підприємств індустрії туристської гостинності повинна бути покладена динамічна концепція якості обслуговування, що базується на постійному отриманні зворотної інформації від споживачів. Нині ж спостерігається недостатній рівень культури гостинності на рівні міст та на місцях туристичної зацікавленості, що суттєво утруднює процеси становлення туризму й на Рівненщині.

На розвиток галузі культури і туризму у 2020 році виділено 100 млн 210 тис. грн, що складає 6\% видаткової частини обласного бюджету.

Висновки. Отже, проведений аналіз сучасного стану ринку туристичних послуг у Рівненській області довів доцільність та необхідність розвитку туристичної галузі. Переваги становлення туризму в містах і на територіях їхнього розташування очевидні. Окрім збільшення кількості робочих місць, це впровадження туристичних продуктів, що характеризуватиме область якнайкраще, також збільшення платоспроможності та життєвого рівня населення місцевості. А це, в свою чергу, спричинить підвищення прибуткової частини бюджету та видатків на історико-культурне відродження міст і регіону в цілому. Без сучасних інвестиційно привабливих, гнучких, клієнтоорієнтованих підприємств, неможлива успішна інтеграція у світовий економічний простір, підвищення добробуту народу, розвиток інноваційної економіки, сталий розвиток територій. Тому, на сучасному етапі, розвиток ринку туристичних послуг заслуговує на особливу увагу 3 боку керівництва області i відповідних підприємств.

Туристична галузь на Рівненщині, хоч і повільними кроками, все ж збільшує свої показники. I саме від того, яким шляхом надалі піде розвиток значно залежить їі майбутнє, майбутнє економіки Рівненської області та України в цілому.

1. Про схвалення Стратегії розвитку туризму та курортів на період до 2026 року: розпорядження Кабінету Міністрів України. URL: http://zakon.rada.gov.ua/laws/show/168-2017-p. (дата звернення: 27.11.2020). 2. Божко Л. Д. Проблеми розвитку сталого туризму в Україні в умовах глобалізації. Вісник Національної академії керівних кадрів культури $i$ мистецтв. 2014.№ 2. С. 43-50. 3. Василькевич Л. О. Оцінка соціальноекономічного ефекту становлення туристичної сфери Рівненщини у господарському комплексі регіону. Економіка. Управління. Інновації. Сер. Економічні науки. 2010. № 2. URL: http://nbuv.gov.ua/UJRN/eui_2010_2_10. (дата звернення: 27.11.2020). 4. Грянило А. В., Мацур Н.І. Міжнародний 
туризм: проблеми та перспективи розвитку в Україні. Фінансовий простір. 2013. № 4. С. 144-148. 5. Григор'єва Я. В. Проблемні аспекти розвитку туризму в Україні. Науковий вісник Львівського державного університету внутрішніх справ. Сер. Економічна. 2011. Вип. 2. С. 118-126. 6. Коніщева Н. І., КушіровичН. О. Методичні підходи до оцінки соціальних, економічних та екологічних наслідків розвитку туризму: туристичного-краєзнавчі дослідження. К. : Кармаліта, 1999. Вип. 2. 356 с. 7. Павленко Л. В. Сучасний стан і проблеми розвитку туризму в Україні. Управління розвитком. 2013. № 15. С. 104-107. 8. Папирян Г. А. Экономика туризма. М. : Финансы и статистика, 2000. 199 с. 9. Головне управління статистики у Рівненській області. URL: http://www.rv.ukrstat.gov.ua (дата звернення: 27.11.2020). 10. Департамент екології та природних ресурсів Рівненської облдержадміністрації. URL: http://www.ecorivne.gov.ua (дата звернення: 27.11.2020). 11. Туризм Рівненщини. URL: http://ogo.ua/rivnenschina/tourizm (дата звернення: 27.11.2020).

\section{REFERENCES:}

1. Pro skhvalennia Stratehii rozvytku turyzmu ta kurortiv na period do 2026 roku : rozporiadzhennia Kabinetu Ministriv Ukrainy. URL: http://zakon.rada.gov.ua/laws/show/168-2017-r. (data zvernennia: 27.11.2020). 2. Bozhko L. D. Problemy rozvytku staloho turyzmu v Ukraini v umovakh hlobalizatsii. Visnyk Natsionalnoi akademii kerivnykh kadriv kultury i mystetstv. 2014. № 2. S. 43-50. 3. Vasylkevych L. 0 . Otsinka sotsialno-ekonomichnoho efektu stanovlennia turystychnoi sfery Rivnenshchyny u hospodarskomu kompleksi rehionu. Ekonomika. Upravlinnia. Innovatsii. Ser. Ekonomichni nauky. 2010. № 2. URL: http://nbuv.gov.ua/UJRN/eui_2010_2_10. (data zvernennia: 27.11.2020). 4. Hrianylo A. V., Matsur N. I. Mizhnarodnyi turyzm: problemy ta perspektyvy rozvytku v Ukraini. Finansovyi prostir. 2013. № 4. S. 144-148. 5. Hryhorieva Ya. V. Problemni aspekty rozvytku turyzmu $v$ Ukraini. Naukovyi visnyk Lvivskoho derzhavnoho universytetu vnutrishnikh sprav. Ser. Ekonomichna. 2011. Vyp. 2. S. 118-126. 6. Konishcheva N. I., Kushirovych N. O. Metodychni pidkhody do otsinky sotsialnykh, ekonomichnykh ta ekolohichnykh naslidkiv rozvytku turyzmu: turystychnoho-kraieznavchi doslidzhennia. K. : Karmalita, 1999. Vyp. 2. 356 s. 7. Pavlenko L. V. Suchasnyi stan i problemy rozvytku turyzmu v Ukraini. Upravlinnia rozvytkom. 2013. № 15. S. 104-107. 8. Papiryan G. A. Ekonomika turizma. M. : Finansyi i statistika, 2000. 199 s. 9. Holovne upravlinnia statystyky u Rivnenskii oblasti. URL: http://www.rv.ukrstat.gov.ua (data zvernennia: 27.11.2020). 10. Departament ekolohii ta pryrodnykh resursiv Rivnenskoi oblderzhadministratsii. URL: http://www.ecorivne.gov.ua (data zvernennia: 27.11.2020). 11. Turyzm Rivnenshchyny. URL: http://ogo.ua/rivnenschina/tourizm (data zvernennia: 27.11.2020). 
Petruk V. A. [1; ORCID ID: 0000-0001-8840-0575], Candidate of Engineering (Ph.D.), Associate Professor,

Petruk I. R. ${ }^{[1 ; 0}$ ORCID ID: 0000-0002-4800-1374], Candidate of Economics (Ph.D.), Associate Professor

${ }^{1}$ National University of Water and Environmental Engineering, Rivne

\section{STATISTICAL ANALYSIS OF THE CONDITION, EFFICIENCY AND POTENTIAL OF TOURISM IN RIVNE REGION}

Given the presence in the Rivne region of unique natural and recreational resources, historical and cultural monuments, rich flora and fauna, various recreation areas, which are one of the factors of sustainable tourism development, there is a critically low level of their development, operation and return. The article analyzes the state and dynamics of their use, efficiency, problems and development potential. After all, the formation of the tourism industry in Rivne region is important for the socio-economic development of the region. In particular, the contribution of tourism enterprises to the development of the economy is manifested in the form of economic and social effects of their operation. The economic effect is manifested in the amount of revenues to the budgets of regional and state importance, the amount of investment in the development of infrastructure in the industry; and social - in improving the welfare of society (reducing unemployment, preserving and restoring the natural potential of the region and historical and cultural heritage, raising living standards, etc.). In addition, within the framework of such an overall positive effect on the development of society, which creates a tourist product, the development of tourism infrastructure contributes to strengthening the economy of the region, the state through job creation and development of related industries. That is why the tourism industry in the development strategy of Rivne region until $\mathbf{2 0 2 7}$ is one of the priorities and is designed for $\mathbf{7}$ years. It includes the promotion of the region through the intensification of sports, events, historical and gastronomic tourism, agritourism in "green estates", and stylized ethnic settlements, where you can learn ancient crafts, and cycling routes, which are ennobled and developed every year. The main goals are to expand the range of tourism products, work to increase the potential of tourism service providers. And the future, the future of the economy of Rivne region and Ukraine as a whole depends on the way of further development.

Keywords: recreational resources; tourist products; economic effect; social effect; tourist potential; tourism development strategy. 
Петрук В. А. [1; ORCID ID: 0000-0001-8840-0575], К.Т.Н., доцент,

Петрук И. Р. ${ }^{[1 ;}$ ORCID ID: 0000-0002-4800-1374] к.э.н., доцент

${ }^{1}$ Национальный университет водного хозяйства и природопользования, г. Ровно

\section{СТАТИСТИЧЕСКИЙ АНАЛИЗ СОСТОЯНИЯ, ЭФФЕКТИВНОСТИ И ПОТЕНЦИАЛА ТУРИЗМА В РОВЕНСКОЙ ОБЛАСТИ}

В статье выделены природные и историко-культурные рекреационные, туристические объекты Ровенской области. Раскрыто новейшие подходы к определению эффективности взноса туристических предприятий в развитие экономики от их функционирования. Системно проанализированы состояние и динамика их использования, эффективность, проблемы и потенциал развития. Установлено критически низкий уровень их освоения, эксплуатации и отдачи на современном этапе. Описано влияние нестабильной политической, сложной экономической и социально-культурной ситуации в стране, пандемии коронавируса и введение карантина на уменьшение количества туристов. Выявлены основные проблемы развития туристической индустрии, требующие неотложной государственной поддержки и регулирования.

Ключевые слова: рекреационные ресурсы; туристические продукты; экономический эффект; социальный эффект; туристический потенциал; стратегия развития туризма.

Стаття надійшла до редакції 28.11.2020 р. 